\title{
Distribution of Mannan-degrading Bacteria in Aquatic Environments
}

\author{
Toshiyoshi AraKI* and Manabu KITAMIKADo* \\ (Received April 10, 1978)
}

\begin{abstract}
Mannan-degrading bacteria were isolated by the surface inoculation method from various natural habitats. The Mannan employed was prepared from a green seaweed Codium fragile, and the colonies surrounded with a clear zone on mannan-containing agar media were judged to be mannan-degrading bacteria. In total, 117 isolates were obtained from 433 samples collected from sea, freshwater, and land environments. Identification according to Bergey's Manual of Determinative Bacteriology permitted assignment of most isolates to eight genera: Pseudomonas, Alcaligenes, Klebsiella, Enterobacter, Vibrio, Aeromonas, Moraxella, and Bacillus.

Simultaneously, an enumeration of mannan-degrading bacteria was carried out by the pour plate method. The population density of the bacteria ranged from $0-1.0 \times 10^{3}$ cell $/ \mathrm{m} /$ in coastal sea water, $0-4.0 \times 10^{5}$ cells $/ \mathrm{g}$ in sea bottom mud, $0-5.5 \times 10^{5} \mathrm{cells} / \mathrm{g}$ in seaweed, $0-1.8 \times 10^{5} \mathrm{cells} / \mathrm{ml}$ in river and pond waters, $1.0 \times 10^{5}-8.7 \times 10^{7}$ cells $/ g$ in the intestinal contents of marine and freshwater fish, and $3.0 \times 10^{4}-7.7 \times 10^{8}$ cells $/ g$ in land soil.
\end{abstract}

The polysaccharide, mannan, is an important structural component of plant cell wall as well as cellulose and xylan. It is comprised of $\beta-1,4$ linked $D$-mannopyranose units. The polysaccharide is distributed widely in many seaweeds of Chlorophyceae ${ }^{1,2)}$ and Rhodophyceae, ${ }^{31}$ besides in terrestrial plant seeds such as coffee bean ${ }^{4}$ and ivory nut. $^{5)}$ It is expected that the residues of these marine and terrestrial plants are decomposed by mannan-degrading microbes in nature.

As regards mannan-degrading microbes, there have been reported numerous fungi belonging to genera Rhizopus, Aspergillus, Penicillium, Paecilomyces etc. by many workers, ${ }^{6-8)}$ whereas only the bacterium of Bacillus subtilis has been demonstrated by EMI et al. ${ }^{\text {1 }}$ They found out mannanase activity in the culture fluid of the bacterium, and investigated the characteristic of the enzyme after exhaustive purification. On the other hand, WILLIAMs and DoETSH ${ }^{10}$ isolated some anaerobic streptococci capable of degrading a heteroglycan (galactomannan) from the rumen of Holstein cow, and INouE ${ }^{11 /}$ isolated Aerobacter spp. from the intestine of human by using another heteroglycan (glucomannan) as a substrate, but the mannan-degrading activity of these bacteria was not determined.

Previous investigations of mannan-degrading microbes have been carried out exclusively from the viewpoint of enzymology, and little is known about the distribution of such microbes in natural habitats, especially in aquatic environments including sea area where the members of bacteria must play the decisive roles in the decomposition of various polysaccharides. The purpose of this study was therefore to search for mannan-degrading bacteria in aquatic environments and to determine their population densities.

\section{Materials and Methods}

\section{Mannan}

A green seaweed Codium fragile was collected from the coastal area of Fukuoka-city, and mannan was isolated with hot $20 \%$ sodium hydroxide solution after exhaustive extraction of the weed with water and cold dilute alkali, according to the method of Love and Percival. ${ }^{1)}$ This was purified by the formation of insoluble copper complex with FeHLING's solution. Treatment with ethanolic hydrogen chloride liberated the free mannan as a white powdery material $(2.7 \%$ of the dried weed). The material, $[\alpha]_{\mathfrak{D}}-40^{\circ}--42^{\circ}$ (c 1.33 in $95 \%$ formic acid), comprised $85-90 \%$ sugar (phenol sulfate method), $9.8 \% \mathrm{H}_{2} \mathrm{O}, 2.2 \%$ ash and $0.1 \%$ protein (KJELDAHL method). After acidic hydrolysis, the sugar component gave $95 \%$ or more D-mannose and a trace amount of glucose by means of gas chromatography (TMS-derivative) and paper chromatography (solvent, $n$-butanol:

* Depertment of Fisheries, Faculty of Agriculture, Kyushu University 46-04, Hakozaki, Higashi-ku, Fukuoka, 812, JAPAN (荒木利芳・北御門 学: 九州大学農学部水産学科). 
pyridine: water $=6: 4: 3$ ).

\section{Samples for the Source of Mannan-degrading Bacteria}

Four hundred and thirty-three samples, which were collected during 1972 through 1977 in Kyushu, Chubu and Hokkaido areas, were examined. The samples of marine origin included: 28 from coastal sea water, 30 from bottom mud of coastal sea (depth 0 to $20 \mathrm{~m}$ ), 50 from seaweed (green, brown and red weeds), 20 from marine plankton (mixture of zoo- and phytoplankton collected in coastal sea), 67 each from gills and intestinal contents of marine fish, and 38 from alimentary canal contents of marine shellfish, mollusk and crustaceous. The samples from freshwater origin included: 15 from river water, 14 from pond water, and 12 each from gills and intestinal contents of freshwater fish. Besides these, 80 samples from land soil were examined for reference.

\section{Bacterial Media}

The basal medium used for the development of marine bacteria comprised $0.5 \%$ peptone and $0.1 \%$ yeast extract in filtered sea water, and the $\mathrm{pH}$ was adjusted to 7.4-7.6. The basal medium for freshwater and land bacteria was nutrient broth, pH 7.2-7.4. These basal media were used after adding suitable amount of mannan and solidifying with $1.5 \%$ agar where necessary.

\section{Method of Screening for Mannan-degrading Bacteria}

Before the screening, each solid sample was blended with a small volume of either sterilized sea water (for samples of marine origin) or physiological saline solution (for those of freshwater and land origin). A small quantity of the sample was streaked on the surface of agar medium containing $1.5 \%$ mannan in a petri dish, and the seeded medium was incubated aerobically at $25^{\circ} \mathrm{C}$. After 1 to 7 days incubation, the colonies which were surrounded with clear zone (see Fig. 1) were selected as mannan-degrading bacteria. The purity of selected bacteria was then assured by repeated single-colony isolations. Finally, isolated mannan-degrading bacteria were grown on agar slant media containing $0.2 \%$ mannan, stored in a refrigerator, and transferred monthly on homologous agar media to maintain viability.

\section{Identification Method}

Identification of mannan-degrading bacteria was

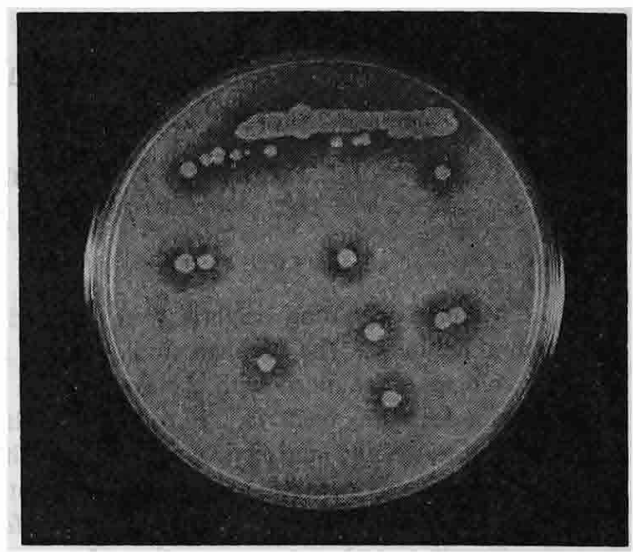

Fig. 1. Clear zones indicating the decomposition of $\beta-1,4-$ mannan in the plate medium. Incubation was carried out at $25^{\circ} \mathrm{C}$ for 2 days.

made according to 8th edition of Bergey's Manual of Determinative Bacteriology. ${ }^{12)}$ Some guide books $^{13-15}$ for bacterial identification were used. The media used here were the same as basal media described above, and the incubation temperature was $25^{\circ} \mathrm{C}$. Motility, morphology, and gramstaining characteristics were determined by light microscopy. The oxidase test of Kovacs ${ }^{161}$ was used, and attack on glucose (OF test) was investigated by the method of HUGH and LeIFSON. ${ }^{17)}$ Sensitivity to 2, 4-diamino-6, 7-diisopropyl pteridine (Vibriostatic agent 0/129) was measured by the method of SHEwAN et al. ${ }^{18)}$ Other usual identification methods were employed as required.

\section{Enumeration of Heterotrophic and Mannan-degrad- ing Bacteria}

A portion of the samples described above were employed. The population density of heterotrophic bacteria in each sample was determined by pour plate count method on the media without added mannan, and that of mannan-degrading bacteria was obtained by counting the colonies which were accompanied with clear zone on the media with $1.5 \%$ mannan.

\section{Enzymatic Degradation of Mannan by Bacterial Culture Fluid \\ Cells taken from agar slant cultures of each isolate were transferred to $20-\mathrm{m} l$ lots of sterile media containing $0.2 \%$ mannan in $50-\mathrm{m} l$, cotton- plugged flasks which were then incubated at $25^{\circ} \mathrm{C}$ for 3 days. Each culture was centrifuged, and the culture fluid obtained was used as enzyme solu- tion. To $10.0 \mathrm{ml}$ of $1.0 \%$ mannan suspension in}


$0.05 \mathrm{M}$ acetate buffer, $\mathrm{pH} 6.0$, was added $2.0 \mathrm{ml}$ of the culture fluid, and the whole was incubated at $37^{\circ} \mathrm{C}$. At intervals, $1.0 \mathrm{ml}$-portion was withdrawn from the reaction mixture, and the reducing sugar formed was determined as mannose by SOMOGYI-NELSON's method, and the hydrolysis rate of the substrate was calculated. As controls, enzyme and substrate solutions were incubated separately, and both were mixed after heating the enzyme in boiling water bath for $3 \mathrm{~min}$.

\section{Chemicals}

Dry media and materials for the preparation of media were obtained commercially from Difco Laboratories (U.S. A), Eiken Chemical Co., and Daigo Eiyokagaku Co. Other chemicals were obtained from Sigma Chemical Co. (U. S. A.), Wako Chemical Co. and other commercial sources.

\section{Results}

\section{Screening of Mannan-degrading Bacteria}

From 300 samples collected in coastal sea, 53 samples in river and pond, and 80 samples in land soil (433 samples in all), were obtained respectively 60,20 and 37 isolates (117 isolates in all) capable of forming clear zone. These isolates were subjected to following mannanase-assay and identification procedures.

\section{Enzymatic Degradation of Mannan by Bacterial Culture Fluid}

This experiment was made to authenticate the active degradation of mannan by isolates. As the results, the culture fluids of all isolates were able to release more or less detectable amount of reducing sugar from mannan. The degradation rates of mannan by representative two isolates are shown in Fig. 2. One of them, No. F-25 strain isolated from intestinal contents of rainbow trout Salmo gairdneri irideus, showed the highest productivity of extracellular mannanase among all isolates, and another, No. F-26 strain isolated from land soil, showed the second high productivity of the enzyme. Of $100 \mathrm{mg}$ mannan which had been added initially into the reaction mixture, about $9 \mathrm{mg}$ mannan was degraded within $30 \mathrm{~min}$, $12 \mathrm{mg}$ within $60 \mathrm{~min}$. and $16 \mathrm{mg}$ within $150 \mathrm{~min}$ by the culture fluid of No. F-25 strain.

\section{Identification of Isolates}

Genera assignments, numbers of isolates, and their main sources are summarized in Table 1 .

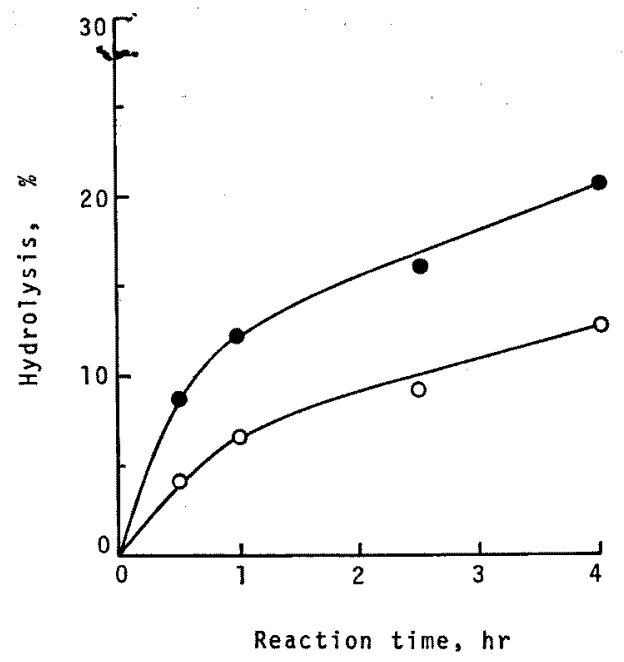

Fig. 2. Time course of hydrolysis of mannan by bacterial mannanase.

- No. F-25 strain; O-O, No. F-26 strain.

In total, 101 of 117 isolates were assigned to eight genera, but the genus of 16 isolates was unknown.

Population Density of Mannan-degrading Bacteria

Enumeration results for mannan-degrading and heterotrophic bacteria in various samples collected from aquatic environments are shown in Table 2. As the results, a considerable number of mannandegrading bacteria were recognized widely in those samples. For comparison, the enumeration was also made using land soil, and the result obtained is shown in the Table.

\section{Discussion}

In this experiment, mannan-degrading bacteria were detected in various kinds of samples collected from coastal sea, river and pond, and land soil. Besides, such bacteria are probable to belong to bacterial genera which are found ordinarily in aquatic and land environments. These facts display that mannan-degrading bacteria are distributed widely in natural aquatic environments as well as in terrestrial environment. From the result in Table 1, however, the predominants of mannan-degrading bacteria seem to be the members of genera Vibrio and Pseudomonas in coastal area, those of genus Aeromonas in river and pond, and those of genus Bacillus in land soil.

Even in the indivisual kinds of samples collected from sea environment, the population density of 
Table 1. Genera of mannan-degrading bacteria isolated from natural habitats

\begin{tabular}{|c|c|c|c|}
\hline Places & Genera & $\begin{array}{l}\text { Number of } \\
\text { isolates }\end{array}$ & Main sources \\
\hline \multirow{7}{*}{ Coastal } & Vibrio & 33 & $\begin{array}{l}\text { Seaweed } \\
\text { Marine plankton } \\
\text { Intestine of marine fish } \\
\text { Alimentary canal of shellish }\end{array}$ \\
\hline & Pseudomonas & 15 & $\begin{array}{l}\text { Gills of marine fish } \\
\text { Sea water } \\
\text { Sea bottom mud }\end{array}$ \\
\hline & Aeromonas & 4 & $\begin{array}{l}\text { Sea water } \\
\text { Marine plankton }\end{array}$ \\
\hline & Alcaligenes & 3 & $\begin{array}{l}\text { Sea water } \\
\text { Seaweed }\end{array}$ \\
\hline & Moraxella & 1 & Sea water \\
\hline & Unknown & 4 & $\begin{array}{l}\text { Seaweed } \\
\text { Gills of marine fish }\end{array}$ \\
\hline & (Total & $60)$ & \\
\hline \multirow{4}{*}{ River and pond } & Aeromonas & 11 & $\begin{array}{l}\text { Intestine and gills of freshwater } \\
\text { fish }\end{array}$ \\
\hline & Enterobacter & 5 & $\begin{array}{l}\text { River water } \\
\text { Pond water }\end{array}$ \\
\hline & Unknown & 4 & Intestine of freshwater fish \\
\hline & (Total & 20) & \\
\hline \multirow{9}{*}{ Land soil } & Bacillus & 12 & - \\
\hline & Pseudomonas & 6 & \\
\hline & Alcaligenes & 6 & , \\
\hline & Aeromonas & 2 & \\
\hline & Klebsiella & 1 & Land soil \\
\hline & Enterobacter & 1 & \\
\hline & Moraxella & 1 & \\
\hline & Unknown & 8 & \\
\hline & (Total & 37) & \\
\hline
\end{tabular}

Table 2. Population density of heterotrophic and mannan-degrading bacteria in natural habitats

\begin{tabular}{lccc}
\hline \multirow{2}{*}{ Specimens } & \multirow{2}{*}{$\begin{array}{c}\text { Number of } \\
\text { samples }\end{array}$} & \multicolumn{2}{c}{ Number of cells/g or ml } \\
\cline { 2 - 4 } & 18 & $4.0 \times 10^{3}-4.8 \times 10^{6}$ & Mannan-degrading \\
\hline Sea water & 18 & $3.0 \times 10^{3}-2.8 \times 10^{6}$ & $0-1.0 \times 10^{8}$ \\
Sea bottom mud & 18 & $1.7 \times 10^{5}-5.7 \times 10^{7}$ & $0-4.0 \times 10^{8}$ \\
Sea weed & 10 & $4.9 \times 10^{2}-2.6 \times 10^{6}$ & $0-5.5 \times 10^{8}$ \\
River water & 10 & $8.6 \times 10^{2}-3.2 \times 10^{5}$ & $0-1.8 \times 10^{5}$ \\
Pond water & 10 & $6.4 \times 10^{7}-1.7 \times 10^{9}$ & $0.0 \times 10^{5}-1.5 \times 10^{4}$ \\
Intestine of marine fish & 10 & $1.0 \times 10^{7}-3.7 \times 10^{9}$ & $1.0 \times 10^{5}-8.7 \times 10^{7}$ \\
Intestine of freshwater fish & 10 & $6.0 \times 10^{5}-2.9 \times 10^{7}$ & $3.0 \times 10^{4}-7.7 \times 10^{5}$ \\
\hline
\end{tabular}

mannan-degrading bacteria varied considerably with each sample. For example, in 10 of 18 samples of sea water, in 8 of 18 samples of bottom mud, and in 8 of 18 samples of seaweed, any of mannan-degrading bacteria were not detected. In the remainning samples, moreover, the population densities varied between $10^{1}-10^{5}$ cells $/ \mathrm{m} l$ or g. Thus, the members of mannan-degrading bacteria would be enriched on the placies where mannan occurs.

INOUE ${ }^{11)}$ has given an attention to the occurrence of a glucomannan-degrading bacteria in human intestine, and INNAMI ${ }^{19)}$ has suggested the possible contribution of human enteric bacteria to the diges- 
tion of konjac flour containing glucomannan. In this experiment, a number of mannan-degrading bacteria were always recognized from intestinal contents of marine and freshwater fish. It will be also of great importance, therefore, to consider the connection of enteric bacteria with seaweed digestion by fish.

FujISAwA and MURAKami ${ }^{20,211}$ determined the population density of $\beta$-1, 4-xylan-degrading bacteria in sea water, bottom sediment and seaweed, and reported the values of $0-5 \times 10^{1}$ cells $/ \mathrm{ml}$, $1.0 \times 10^{3}-1.3 \times 10^{5} \mathrm{cells} / \mathrm{g}, \quad 1.0 \times 10^{2}-5.0 \times 10^{6} \mathrm{cell} / \mathrm{g}$ respectively. They also reported respectively the values of $0-6$ cells $/ \mathrm{ml}, \quad 1.0 \times 10^{1}-3.0 \times 10^{4}$ cells $/ \mathrm{g}$, and $0-2.1 \times 10^{5}$ cells/g as the density of $\beta-1,3-$ xylan-degrading bacteria. Therefore, the population density of mannan-degrading bacteria may be almost same as those of $\beta-1,3-x y l a n-$ and $\beta-1$, 4-xylan-degrading bacteria in sea environment.

\section{Acknowledgement}

The authors acknowledge helpful discussions with Professor M. Toyomizu, Kyushu University, on several points in the paper.

\section{References}

1) J. Love and E. Percival: J. Chem. Soc., 33453350 (1964).

2) Y. IRIKI and T. MiWA: Nature, 185, 178-179 (1960).

3) J. K. N. Jones: J. Chem. Soc., 3292-3295 (1950).

4) M. L. Wolfrom, M. L. LAVER, and D. L. Patin: J. Org. Chem., 26, $4533-4535$ (1961).

5) G. O. Aspinall, E. L. Hirst, E. G. V. Percival, and I. R. WILliamson: J. Chem. Soc., 31843188 (1958).

6) E. T. Reese and Y. Shibata: Can. J. Microbiol, 11, 167-183 (1965).

7) Y. Hashimoto and J. Fukumoto: Nippon Nogeikagaku Kaishi, 43, 317-322 (1969).

8) Y. Tsujisaka, K. Hiyama, S. Takenishi, and J. Fukumoto: Nippon Nogeikagaku Kaishi, 3, 155161 (1972).

9) S. EmI, J. Fukumoto, and T. Yамамото: Nippon Nogeikagaku Kaishi, 36, 991-1001 (1972).

10) P. P. Wrlliams and R. N. Doetsh: J. Gen. Microbiol., 22, 635-644 (1960).

11) N. Inoue: The Japanese J. Nutrition, 2, 9-18 (1942).

12) R. E. Buchanan and N. E. Gibbons: Bergey's Manual of Determinative Bacteriology, 8th ed. (1974).

13) S. T. Cowan and K. J. Steel: Manual for the identification of medical bacteria, Cambridge University Press, London (1965).

14) B. M. Gibbs and F. A. SKinner: Identification Methods for Microbiologists, Part A and B, Academic Press, London and New York (1966).

15) P. R. EdWards and W. H. EwING: Identification of Enterobacteriaceae, Burgess Publishing Co., Minnesota (1962).

16) N. Kovacs: Nature, 178, 703 (1956).

17) R. Hugh and E. Leifson: J. Bacteriol., 66, 2426 (1953).

18) J. M. Shewan, M. Hodgkiss, and J. Liston: Nature, 173, 208-209 (1954).

19) S. Innami: Agr. Biol. Chem., 25, 155-163 (1961).

20) M. Murakami and H. Fujisawa: Bull. Japan. Soc. Sci. Fish., 34, 11241130 (1968).

21) H. Fujisawa and M. MurakamI: Bull. Japan. Soc. Sci. Fish., 36, 741-747 (1970). 